\title{
9. PRELIMINARY RESULTS FROM HOLE 704A: ARCTIC-ANTARCTIC CORRELATION THROUGH NANNOFOSSIL BIOCHRONOLOGY ${ }^{1}$
}

\author{
Gunilla Gard² and Jason A. Crux ${ }^{3}$
}

\begin{abstract}
The abundance of calcareous nannofossils fluctuates strongly in the upper Quaternary interval of ODP Hole 704A in the southern South Atlantic. These fluctuations are tentatively correlated to the oxygen isotope stratigraphy, which shows that intervals rich in nannofossils represent interglacial time periods. The nannofossil assemblages indicate that during about the last $650,000 \mathrm{yr}$, the surface waters at Site 704 were warmer than at present only in oxygen isotope stage 5 , with probable restriction to substage $5 \mathrm{e}$. The environment was interglacial also during oxygen isotope stages 7,11 , and 13 , whereas stage 3 was characterized by intermediate glacial conditions. The nannofossil assemblages suggest that a significantly colder environment than at present prevailed in isotope stages $2,4,6,8,10$, and 12 .

The fluctuations in nannofossil abundance in Hole $704 \mathrm{~A}$ are correlated to nannofossil abundance patterns in the Norwegian Sea. During the last $500,000 \mathrm{yr}$, total abundances of nannofossils fluctuate in similar patterns in both the subantarctic and subarctic areas studied. Nannofossils were rare in the subarctic area between about $500,000 \mathrm{yr}$ to over $1 \mathrm{~m} . \mathrm{y}$. ago, but were deposited in abundance around $650,000 \mathrm{yr}$ ago in the subantarctic area.
\end{abstract}

\section{BACKGROUND AND OBJECTIVES}

Ocean Drilling Program (ODP) Hole 704A was drilled about $2.5^{\circ}$ north of the Antarctic Convergence Zone (ACZ) and approximately $5^{\circ}$ south of the Subtropical Convergence. The site is located under Subantarctic Surface Water (SSW) present at the northernmost edges of the Antarctic Circumpolar Current (ACC) (Fig. 1). The strong hydrographic gradients make the location of Site 704 sensitive to climatic/oceanographic changes. The main objectives at Site 704 were to document the development of the ACC and the history of major northward excursions of the Polar Front. Another objective was to compare the record from Site 704 to glacialinterglacial fluctuations in the northern North Atlantic. The sedimentary sequence recovered from Site 704 is the thickest and most complete section at high southern latitudes that contains carbonate and abundant microfossils throughout (Shipboard Scientific Party, 1988).

In the Norwegian Sea, at the northernmost stretches of the North Atlantic, numerous oscillations of the Arctic Polar Front during the late Quaternary have been documented through quantitative studies of foraminifers and calcareous nannofossils and oxygen isotope data (Kellogg et al., 1978; Belanger, 1982; Gard and Backman, in press). Detailed correlations between the oxygen isotope stratigraphy and nannofossils in the Norwegian Sea show that nannofossil abundance and assemblage variations reflect climatic changes. Layers with abundant nannofossils represent interglacial time periods, and intermediate glacial-full glacial interval layers have few, or no, nannofossils (Gard, 1988). As the species compositions are also observed to vary rapidly through time, some age determinations can be made from the nannofossil assemblages in cores without oxygen isotope stratigraphy.

The nannofossil abundance patterns during the late Quaternary are virtually unknown in the high latitudes of the Southern Hemisphere. This study aims (1) to establish an

\footnotetext{
${ }^{1}$ Ciesielski, P. F., Kristoffersen, Y., et al., 1991. Proc. ODP, Sci. Results, 114: College Station, TX (Ocean Drilling Program).

2 Department of Geology, University of Stockholm, S-106 91, Stockholm, Sweden.

${ }^{3}$ BP Exploration, 5151 San Felipe, P.O. Box 4587, Houston, TX, 77210.
}

upper Quaternary quantitative nannofossil biostratigraphy at Hole $704 \mathrm{~A}$ in the southern South Atlantic, (2) to obtain an absolute chronology for the biostratigraphy by correlating the nannofossil datum events to the oxygen isotope stratigraphy and other available absolute ages, (3) to interpret the nannofossil abundance patterns in paleoceanographic terms, and (4) to compare the nannofossil abundance patterns to those in the northern North Atlantic.

In a wider context, this study aims to contribute toward the understanding of Pliocene-Pleistocene climatic change by documenting paleoceanographic evolution within a reliable chronostratigraphic framework. In order to achieve these objectives, the nannofossil biostratigraphy needs to be integrated with results from other studies, particularly of oxygen isotope stratigraphy and other microfossil groups. The present paper reports on the preliminary results obtained from semiquantitative studies of calcareous nannofossils.

\section{MATERIALS AND METHODS}

ODP Hole 704A was drilled on the central southern part of the Meteor Rise in the southeastern South Atlantic $\left(46^{\circ} 53^{\prime} \mathrm{S}\right.$, $07^{\circ} 25^{\prime} \mathrm{E}$; water depth of $2532 \mathrm{~m}$ ) (Figs. 1 and 2). The hole was cored continuously using the advanced hydraulic piston corer and extended core barrel to recover an upper Miocene to Quaternary sedimentary sequence. The topmost three cores studied in the present paper penetrated $26.2 \mathrm{~m}$, averaging an apparent recovery of over $100 \%$, which suggests that core loss was minimal. The sediments are highly variable in color and lithology at intervals of about 20 to $100 \mathrm{~cm}$. Generally, the lighter color intervals (light yellow and light gray to white) correspond to high carbonate content, whereas the darker colors (olive and pale olive) correspond to diatom-rich intervals and low carbonate values (Shipboard Scientific Party, 1988). The contacts between the lithologic and color changes are generally sharp. During sampling, efforts were made to avoid intervals that showed signs of disturbance.

Calcareous nannofossils recovered from ODP Hole 643A $\left(67^{\circ} 43^{\prime} \mathrm{N}, 01^{\circ} 02^{\prime} \mathrm{E}\right.$; water depth $\left.2764 \mathrm{~m}\right)$ (Fig. 2) in the Norwegian Sea have been studied previously (Eldholm, Thiede, et al., 1987; Gard, 1988; Gard and Backman, in press). The Norwegian Sea is today influenced by the Norwegian Current, a northern extension of the Gulf Stream. The surface waters at 


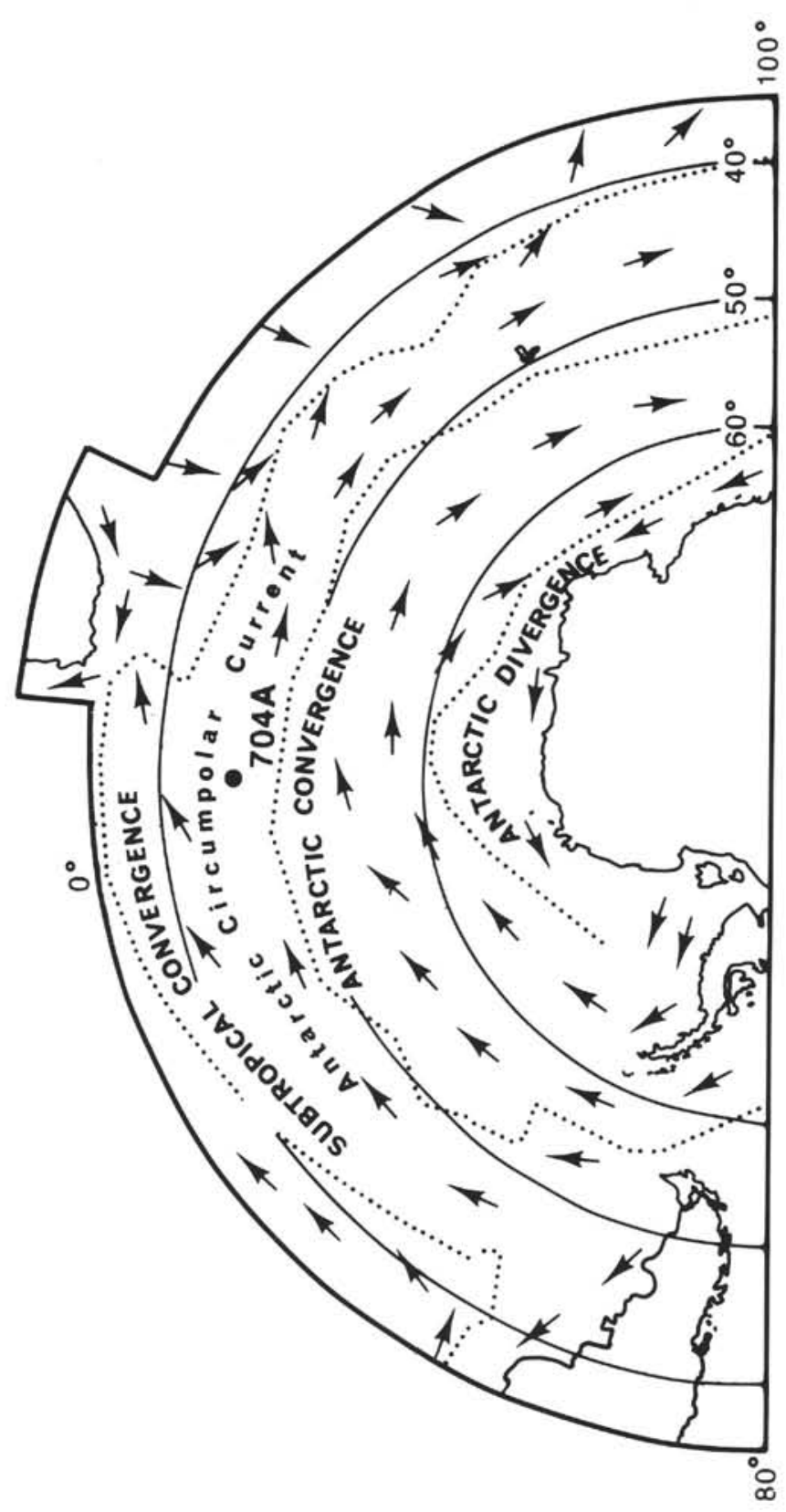

Figure 1. Oceanographic setting, Hole 704A.

these high latitudes are south of the Arctic Convergence Zone for most of the year and can be described as subarctic. For reference purposes, Cores V22-108 from the South Atlantic $\left(43^{\circ} 11^{\prime} \mathrm{S}, 03^{\circ} 15^{\prime} \mathrm{W}\right.$; water depth $\left.4171 \mathrm{~m}\right)$ and $\mathrm{RC} 11-120$ from the Indian Ocean ( $43^{\circ} 31^{\prime} \mathrm{S}, 7^{\circ} 52^{\prime} \mathrm{E}$; water depth $\left.3193 \mathrm{~m}\right)$ and DSDP Hole 552A from the northern North Atlantic $\left(56^{\circ} 03^{\prime} \mathrm{N}\right.$, $23^{\circ} 13^{\prime} \mathrm{W}$; water depth $2311 \mathrm{~m}$ ) are also included in this study (Fig. 2). The detailed nannofossil stratigraphy of these holes can be found in Gard (1988, 1989), with further details in Hays et al. (1976), Martinson et al. (1987), and Shackleton and Hall (1984).

Smear slides were prepared from Hole 704A intervals of about $20 \mathrm{~cm}$. These were studied with light microscope at $\times 1500$ magnification. The small placoliths (Emiliania huxleyi and Gephyrocapsa spp.) are the most common taxon by several orders of magnitude, and their abundance was determined by counting those present in two fields of view. The

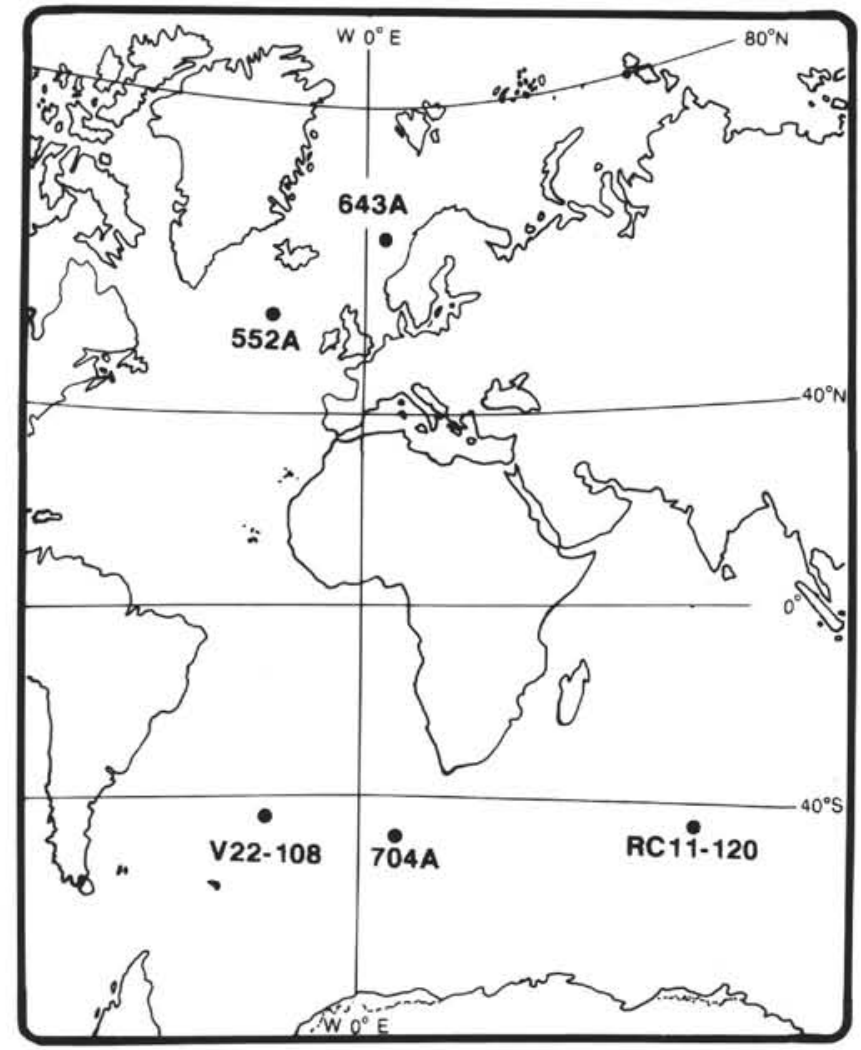

Figure 2. Location map of core recovery included in this study.

small placoliths at certain levels were subdivided into three morphogroups that have been shown to be useful for stratigraphical purposes (Gard and Backman, in press). Morphogroup 1 consists of specimens $>2.5 \mu \mathrm{m}$ in length that can be observed in the light microscope to possess a clearly open central area spanned by a bridge. Specimens $<2.5 \mu \mathrm{m}$ are assigned to group 2 , and group 3 consists of specimens $>2.5$ $\mu \mathrm{m}$ in length that appear in the light microscope to have a closed, or almost closed, central area spanned by a short bridge. The taxonomy of the genus Gephyrocapsa is ambiguous and many species are difficult to differentiate. However, specimens of group 1 can be referred to as Gephyrocapsa muellerae, group 2 as Gephyrocapsa aperta, and group 3 as Gephyrocapsa caribbeanica, although other species also are involved (Gard, 1988). Samtleben (1980) presented an overview of the genus Gephyrocapsa. The relative abundances (expressed as percentages) between the morphogroups were determined by counting at least 200 specimens, except at a few levels where nannofossils were rare. The abundance of all other species was determined by counting the specimens in 20 fields of view. In order to make comparisons between different microscopes and magnifications possible, total abundances are expressed as numbers of specimens per square millimeter in the smear slide. This method is shown to reflect the true major abundance variations of nannofossils reliably (specimens per gram sediment) (Backman and Shackleton, 1983). The identifications of $E$. huxleyi were made in a scanning electron microscope (SEM).

Hole $643 \mathrm{~A}$ was studied using the same methods, except that the magnification used for estimating abundance was $\times 800$ and that all abundances were counted from 25 fields of view. Nannofossils in Cores V22-108 and RC11-120 and Hole $552 \mathrm{~A}$ were studied in samples taken at about $10-\mathrm{cm}$ intervals. The relative abundance among the three morphogroups of the 
imall placoliths was determined using a magnification of about $\times 1250$.

\section{NANNOFOSSIL STRATIGRAPHY AND CHRONOLOGY}

Figure 3 shows nannofossil abundances correlated to oxyzen isotope stratigraphy (sinistrally coiled Neogloboquadrina sachyderma; Hodell and Ciesielski, this volume) and calcium sarbonate variations (Shipboard Scientific Party, 1988) in Hole 704A. The upper $9.5 \mathrm{~m}$ below seafloor (mbsf) is characerized by strongly fluctuating total nannofossil abundances. Between about 9.5 to 18 mbsf is an almost barren interval, and otal abundances fluctuate strongly from about $18 \mathrm{mbsf}$ to the sottom of the studied sequence, at about $26 \mathrm{mbsf}$.

Worldwide established nannofossil events provide some tatum levels. A single specimen of Pseudoemiliania lacunosa was observed at 7.05 mbsf (Sample 114-704A-1H-5, $105 \mathrm{~cm}$ ), but its last continuous occurrence was observed at 8.75 mbsf (Sample 114-704A-2H-2, $4 \mathrm{~cm}$ ). In high latitudes, $P$. lacunosa is extremely rare toward its extinction (Backman and Shackleton, 1983), which marks the Zone NN19/20 boundary (Martini, 1971). This datum was calculated by Thierstein et al. (1977) to occur in mid-oxygen isotope stage 12 at about $460,000 \mathrm{yr}$ ago. We have placed the last appearance datum (LAD) of $P$. lacunosa at 6.95 mbsf (the midpoint between the last sample that contains $P$. lacunosa and the closest sample above) as additional age information is provided by the radiolarian Stylatractus universus, which disappears at about 6.85 mbsf (P. F. Ciesielski, pers. comm., 1989) and is known to have a LAD at about the oxygen isotope stage 11/12 boundary (Hays and Shackleton, 1976).

The Zone NN20/21 boundary is marked by the first appearance of Emiliania huxleyi, a species that we can identify with confidence only in the SEM. In Hole 704A, the lowest sample studied in the SEM where E. huxleyi was present was from 2.54 mbsf (Sample 114-704A-1H-2, $104 \mathrm{~cm}$ ) (Fig. 3). E. huxleyi was absent in samples from 5.94, 4.84, and 4.49 mbsf (Samples 114-704A-1H-4, $144 \mathrm{~cm}, 114-704 \mathrm{~A}-1 \mathrm{H}-4,34 \mathrm{~cm}$, and 114-704A$1 \mathrm{H}-3,149 \mathrm{~cm}$, respectively). Low nannofossil abundance and poor preservation made the results of attempts to study Sample 114-704A-1H-3, $35 \mathrm{~cm}$, from 3.35 mbsf, inconclusive. Thierstein et al. (1977) observed that the first appearance of $E$. huxleyi occurred in mid-oxygen isotope stage 8 at about $258,000 \mathrm{yr}$ ago. We thus conclude that the 2.54 mbsf level is younger than oxygen isotope stage 8 and that the 4.49 mbsf level is older. Thierstein et al. (1977) also noted that E. huxleyi occurs only in low abundances within the lower part of its range and is outnumbered by Gephyrocapsa spp. Subsequently, a shift in dominance between these two taxa occurred, and $E$. huxleyi outnumber Gephyrocapsa spp. This shift in dominance is observed to occur in oxygen isotope substage 5a in high-latitude areas (Thierstein et al., 1977). In Hole 704A, dominant E. huxleyi are observed in samples from 1.74 mbsf (Sample 114-704A-1H-2, $24 \mathrm{~cm}$ ) and above. At $2.34 \mathrm{mbsf}$ (Sample 114-704A-1H-2, $84 \mathrm{~cm}$ ), Gephyrocapsa spp. dominate over $E$. huxleyi. Thus, we conclude that the oxygen isotope substage $5 \mathrm{a} /$ stage 4 boundary is located in between these two levels.

The diatom Actinocyclus ingens is observed to disappear at about 13.25 mbsf (Fenner, this volume), and it has an established LAD at the oxygen isotope stage $15 / 16$ boundary at about 620,000 yr ago (Müller et al., this volume). The Brunhes/Matuyama boundary $(730,000 \mathrm{yr}$; Berggren et al., 1985) occurs between 33.26 and 35.77 mbsf (mean depth $=34.51$ mbsf) (Hailwood and Clement, this volume).

The relationships among the three Gephyrocapsa morphogroups in Core RC11-120 and Holes 552A and 704A are compared in Figure 4. In all three sequences, morphogroup 3 is dominant in the lower part but is subsequently outnumbered by group 2, and in the higher part of the holes, group 1 dominates. The transition from group 3 dominance to group 2 dominance occurs in uppermost stage 8 and in stage 7 in both Core RC11-120 and Hole 552A. We conclude that this is the age of the same transition in Hole 704A. Thus, the oxygen isotope stage $7 / 8$ boundary in Hole $704 \mathrm{~A}$ is located at approximately 3.50 to 4.00 mbsf.

Given this chronostratigraphic framework, it seems reasonable to conclude that intervals with high abundances of nannofossils in Hole 704A represent comparatively warm time periods (oxygen isotope stages with odd numbers) and intervals with low levels of nannofossils represent colder time periods (oxygen isotope stages with even numbers). No detailed oxygen isotope stratigraphy is yet available from Hole $704 \mathrm{~A}$, but the curve based on widely spaced samples (Fig. 3; Hodell and Ciesielski, this volume) clearly indicates that light values (warm waters) occur at levels where nannofossils are abundant. Heavy isotope values (cold waters) occur where nannofossils are rare. In Figure 3, we have marked the tentative levels of oxygen isotope stages 1 to 13. Further support to the interpretation that high abundances of nannofossils represent warm time periods (interglacials) is given by the abundance of Calcidiscus leptoporus, which shows abundance peaks at the supposed levels of oxygen isotope stages 1 and 5. Core V22-108 from the southern South Atlantic and Cores RC8-39 and RC11-120 from the Indian Ocean are dated by oxygen isotopes; in all these cores, as well as in many cores from the North Atlantic and the Norwegian Sea, C. leptoporus is observed to increase in abundance during stages 1 and $5 \mathrm{e}$ (Gard, 1988, 1989). In the South Atlantic and the Indian Ocean, Coccolithus pelagicus is present in slightly higher abundance during stage 3 (Gard, 1989) and in the topmost part of stage 6 . We suggest that the abundance peak of $C$. leptoporus at about 2.54 mbsf in Hole $704 \mathrm{~A}$ represents oxygen isotope substage $5 \mathrm{e}$ and that the $C$. pelagicus peak at about 2.84 mbsf represents stage 6 .

Below the possible oxygen isotope stage 13 interval, the nannofossil abundance patterns are impossible to put into a detailed chronostratigraphic framework because their relationship to the oxygen isotope stratigraphy is unknown and few other datum events are available. Determination of the Brunhes/Matuyama boundary at 34.51 mbsf (Hailwood and Clement, this volume) and the extinction of the diatom $A$. ingens at $13.25 \mathrm{mbsf}$ provides ages of 620,000 and $730,000 \mathrm{yr}$, respectively (Shipboard Scientific Party, 1988). This indicates that the interval between 9.50 and 13.25 mbsf was deposited between about 500,000 to $620,000 \mathrm{yr}$ ago. If these datums are correctly located, they indicate that sedimentation rates increase downcore. Average linear sedimentation rates for the latest interval of about $500,000 \mathrm{yr}$ are calculated to be about $1.9 \mathrm{~cm} / 1000 \mathrm{yr}$ (top of core to $9.5 \mathrm{mbsf}$ ). The interval from 500,000 to about 620,000 yr shows linear sedimentation rates of about $3.1 \mathrm{~cm} / 1000 \mathrm{yr}(9.50$ to $13.25 \mathrm{mbsf})$ and from between about 620,000 and $730,000 \mathrm{yr}(13.25$ to $34.51 \mathrm{mbsf})$ of 19.3 $\mathrm{cm} / 1000 \mathrm{yr}$. This suggests that the bottom of the studied sequence is dated at about $680,000 \mathrm{yr}$.

\section{COMPARISON TO THE NORWEGIAN SEA}

The nannofossil biozonation scheme from the Norwegian Sea (Gard, 1988; Gard and Backman, in press) provides a detailed history of nannofossil abundance fluctuations in this area during the last about $500,000 \mathrm{yr}$. Figure 5 shows the nannofossil abundance patterns in the Norwegian Sea compared to the results in Hole 704A. The total abundance of nannofossils through stages 1 to 13 appears to be similar in the two hemispheres. The main difference is the unrelated abundance pat- 
Abundance (specimens/mm²)

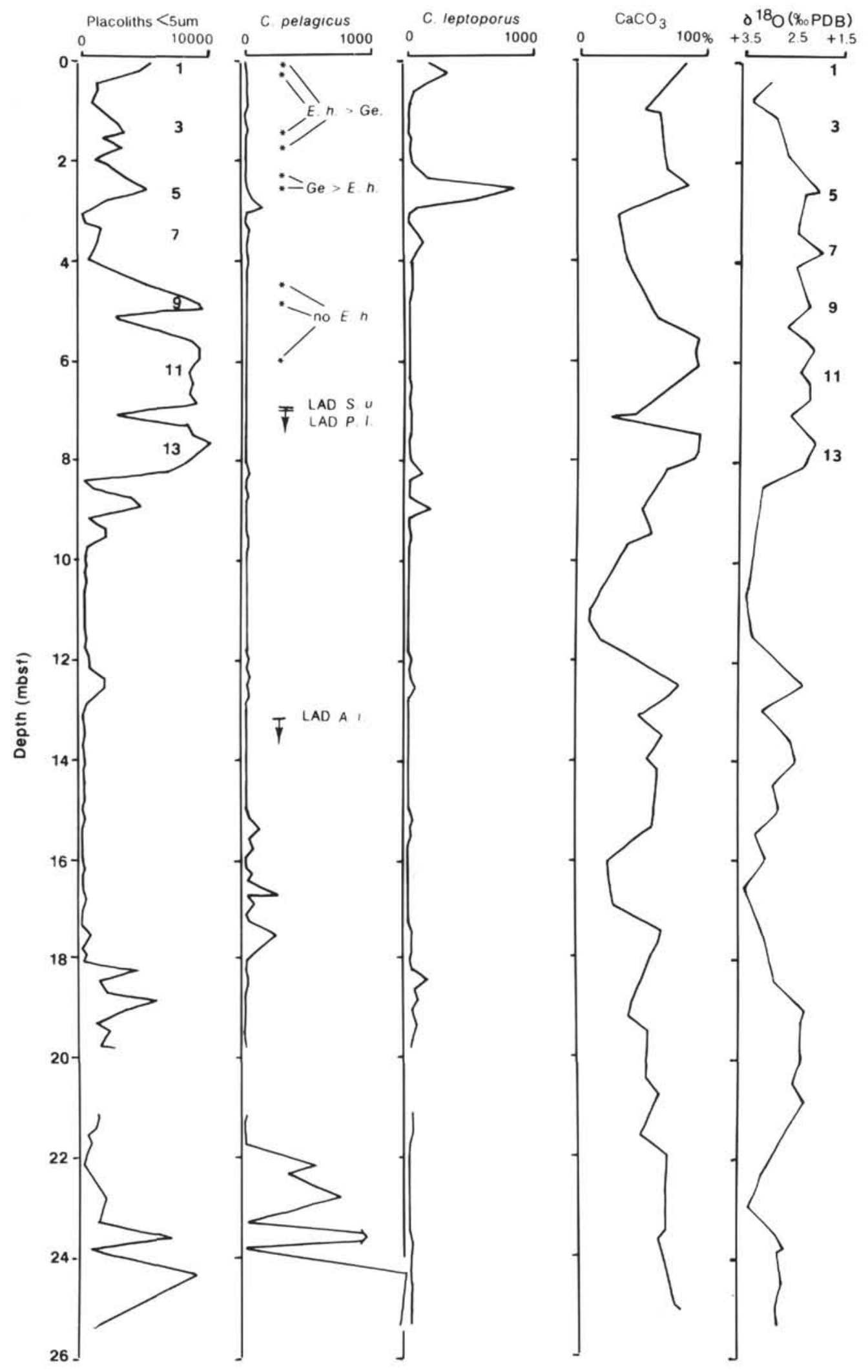

Figure 3. Nannofossil abundance, nannofossil and microfossil datum events, $\mathrm{CaCO}_{3}$ content, and preliminary oxygen isotope statigraphy in Hole 704A. E. $h .=$ Emiliania huxleyi; Ge. $=$ Gephyrocapsa spp.; $S . u .=$ Stylatractus universus; $P . l .=$ Pseudoemiliania lacunosa $;$ A. $i .=$ Actinocyclus ingens. 


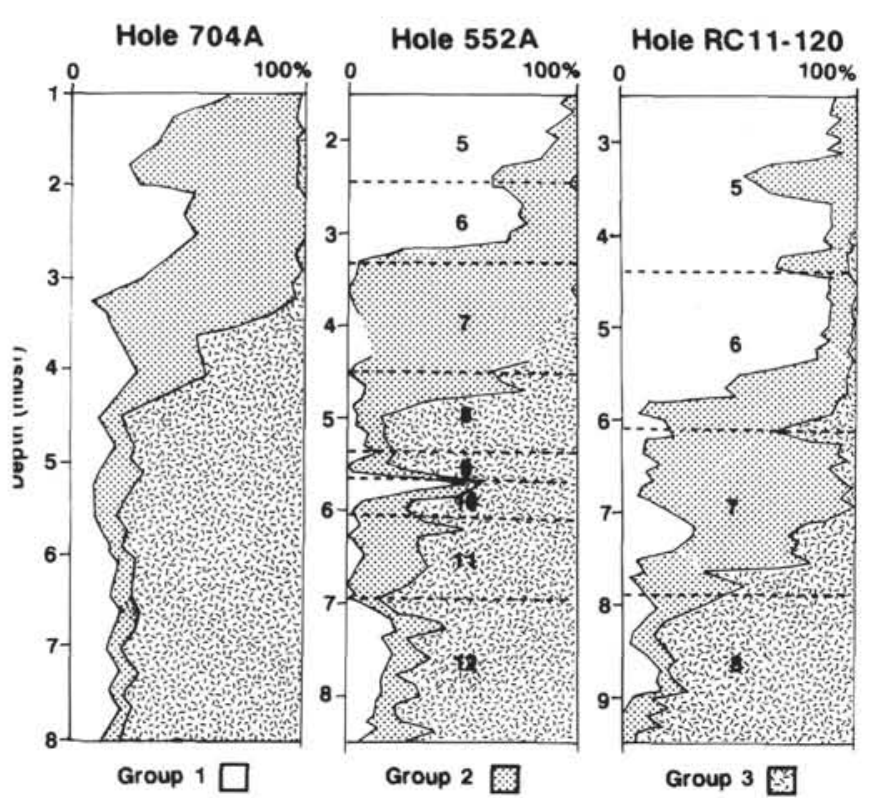

Figure 4. Relative abundance among Gephyrocapsa morphogroups 1, 2, and 3 (Gard, 1988) in Holes 704A and 552A and Core RC11-120 Juring different oxygen isotope stages. Oxygen isotope stage boundaries in Hole 552A are from Shackleton and Hall (1984) and in Core RC11-120 from Martinson et al. (1987).

terns of Coccolithus pelagicus. The present distribution of this species is disjunct, as it occurs mainly in the northern North Atlantic and the northern Pacific (McIntyre et al., 1970). The distribution of this species is likely controlled by an interplay of a number of biologic and oceanographic factors, making a straight correlation to climatic fluctuations impossible (Gard, 1989). Another difference is that Calcidiscus leptoporus is rarer in the Norwegian Sea than in Hole 704A.

ODP Hole $643 \mathrm{~A}$ was analyzed for nannofossil abundance in the topmost seven cores (Fig. 5). Below oxygen isotope stage 13 at about 18 mbsf, this sequence has low carbonate content and is almost barren of nannofossils until about $48 \mathrm{mbsf}$, where high abundances of small placoliths and $C$. pelagicus are present. The Brunhes/Matuyama boundary occurs at about 26.5 mbsf and the Jaramillo event at about 30-32 mbsf (U. Bleil, pers comm., 1989), indicating an age of about +1 m.y. for the nannofossil-rich interval in the lower part of the studied sequence. In Hole 704A, the sediments also contain few nannofossils below oxygen isotope stage 13, but they return well above the Brunhes/Matuyama boundary at an estimated age of about $645,000 \mathrm{yr}$.

\section{PALEOCEANOGRAPHIC INTERPRETATIONS}

The fluctuation of the total abundance of nannofossils in the Norwegian Sea correlates well to North Atlantic climatic variations (Ruddiman and McIntyre, 1976; Gard and Backman, in press). Intervals with high abundances of nannofossils are interpreted to reflect time periods when North Atlantic Drift Water flowed into the Norwegian Sea, keeping the surface waters subpolar rather than glacial. Intervals barren of nannofossils reflect southward movements of the Arctic Polar Front. The nannofossil abundance pattern in Hole 704A indicates that this site has experienced a similar history to the Norwegian Sea and that the present-day environment with subantarctic surface water has changed many times during the time period studied.
The finer details of the time scale for Hole 704A are still tentative and the nannofossil abundance patterns are preliminary, for which the accuracy would probably be improved by an increased sampling interval at least for the upper approximately $10 \mathrm{mbsf}$, where the linear sedimentation rate was slow. However, the data available at present still provide a good framework for basic paleoceanographic interpretations. During oxygen isotope stage 2 , the low abundance of nannofossils suggests a harsher environment in comparison with presentday conditions. Levels with a low abundance of nannofossils can be formed by (1) lower numbers of living individuals close to the Polar Front (none under strictly polar waters) (McIntyre et al., 1972), (2) increased dilution from terrigenous material or diatoms, or (3) calcium carbonate dissolution. We have demonstrated that the highest sedimentation rates occurred in the lower part of the studied sequence, at levels where nannofossils occur most abundantly. Thus, we can exclude factor (2) from determining the nannofossil abundance patterns. We also observe that reported $\mathrm{CaCO}_{3}$ levels (Shipboard Scientific Party, 1988) do not determine nannofossil abundances, as many levels barren of nannofossils are rich in $\mathrm{CaCO}_{3}$ (Fig. 3). Thus, we conclude that the low levels of nannofossils observed in oxygen isotope stage 2 reflect the last glaciation and the northward movement of the ACZ close to the location of Hole 704A.

Oxygen isotope stage 3 is characterized by conditions slightly less favorable to nannofossils than those of today. The short stage 4 is difficult to recognize without a closer sampling interval. Substage $5 \mathrm{e}$ is marked by high abundances of small placoliths and a conspicuous abundance peak of Calcidiscus leptoporus. Sea-surface temperatures estimated from radiolarians during oxygen isotope stages $1-5$ in South Atlantic Core V22-108 (J. D. Hays, pers. comm., 1988) follow abundances of $C$. leptoporus (Fig. 6). We conclude that during the entire time period studied, Site 704 experienced the highest seasurface temperatures in oxygen isotope substage $5 \mathrm{e}$. We also note increased abundances of $C$. leptoporus in stages 1,7 , and 13 and at about $18-19.5$ mbsf. This pattern indicates that during most of the time period studied, Site 704 experienced lower sea-surface temperatures than at present, and only during substage $5 \mathrm{e}$ (about $120,000 \mathrm{yr}$ ago, during the last interglacial) was the environment warmer.

Oxygen isotope stage 6 in Hole $704 \mathrm{~A}$ is marked by sediments almost barren of nannofossils; thus, the area was possibly south of the ACZ at stage 6 time. The increased abundance of $C$. leptoporus in stage 7 may indicate that conditions were mild, although total amounts of nannofossils are moderate. During this time, the assemblage was dominated by very small $(<2.5 \mu \mathrm{m})$ Gephyrocapsa spp. It is possible that the initial abundance was higher, but these small placoliths were partly removed by calcium carbonate dissolution after deposition. The calcium carbonate curve shows a low at this level (Fig. 3). During oxygen isotope stage 8 , the ACZ probably moved closer to Site 704 . High abundances of small placoliths were observed in stages 9 and 11, but without any indicators of subtropical influence. The $\mathrm{ACZ}$ probably made northward excursions during stages 10 and 12.

Between roughly 500,000 to $645,000 \mathrm{yr}$ ago, nannofossils were rare in the area, which may indicate virtually uninterrupted polar regimes. Nannofossils are present in high abundance in the lower part of the analyzed sequence, which has an estimated age in the order of 645,000 to $680,000 \mathrm{yr}$.

\section{CONCLUSIONS}

The abundance of calcareous nannofossils fluctuates strongly in the upper Quaternary interval of Hole 704A. These fluctuations can be used for biostratigraphic purposes. They 


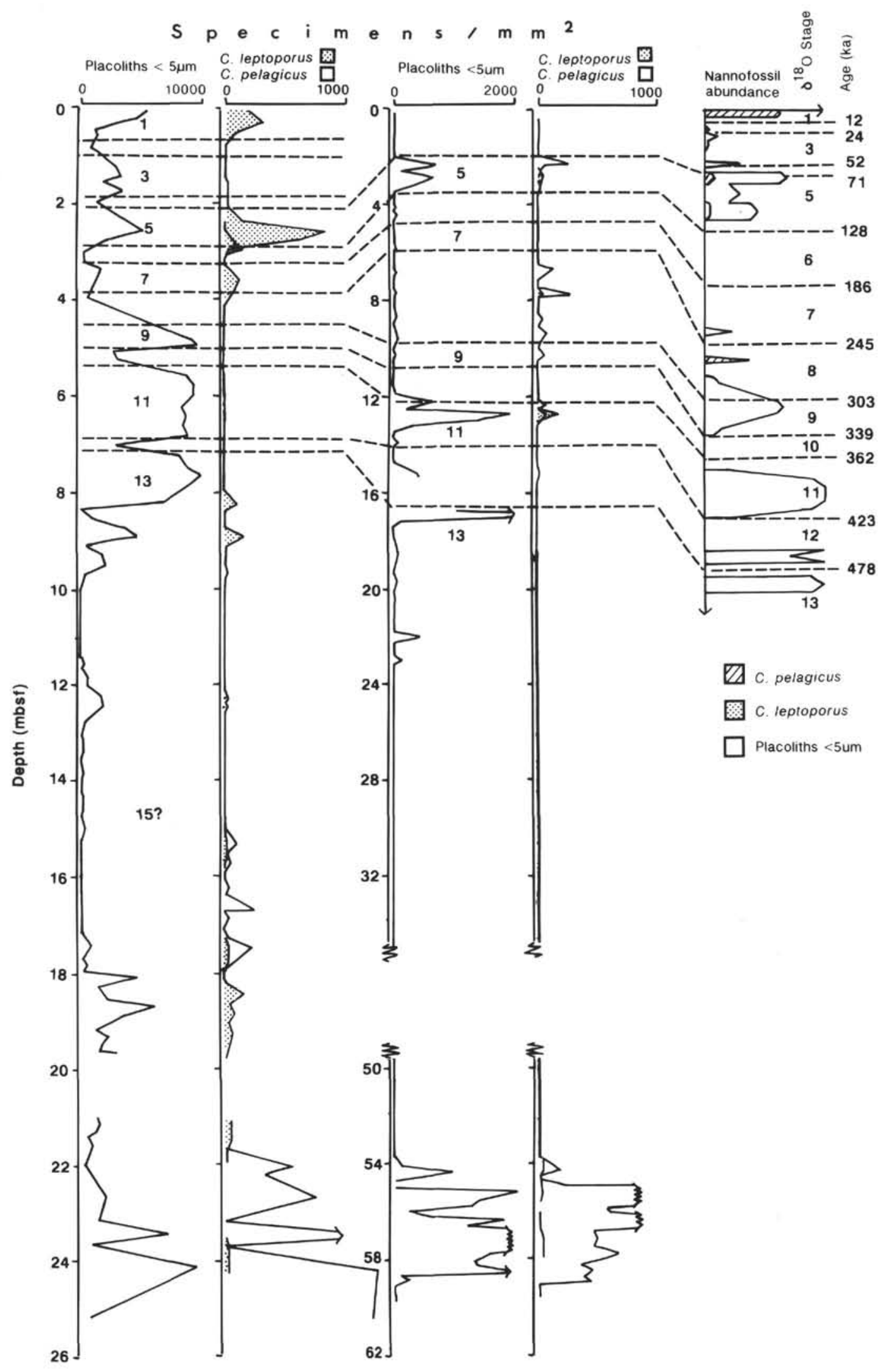

Figure 5. Correlation of nannofossil abundance in Holes 704A and 643A and in the Norwegian Sea during oxygen isotope stages 1 to 13 (composite, idealized section from Gard, 1988; Gard and Backman, in press). Ages of oxygen isotope stage boundaries are from Imbrie et al. (1984). 


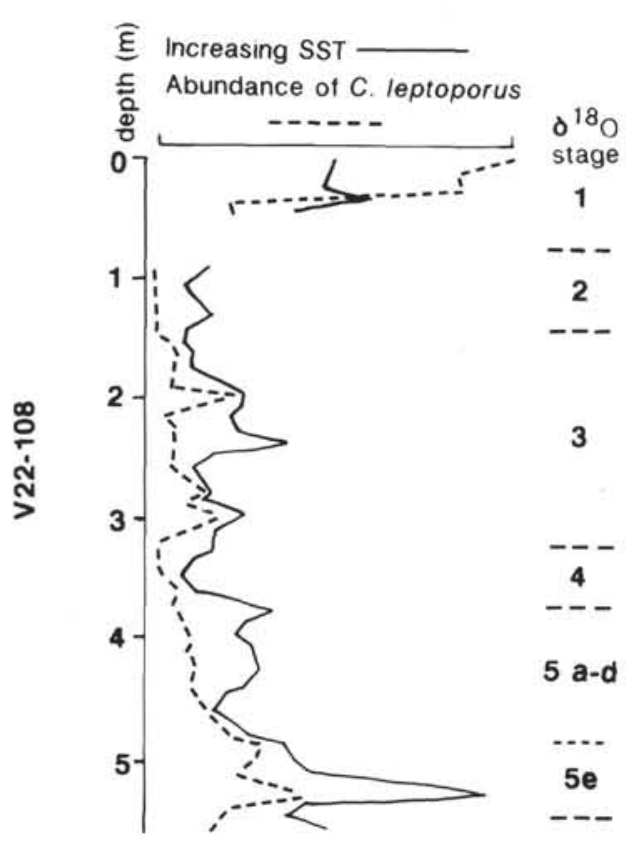

Figure 6. Comparison of estimated sea-surface temperatures (SST) from radiolarians (J. D. Hays, pers. comm., 1988) to abundances of Calcidiscus leptoporus in Core V22-108 in oxygen isotope stages 1 through 5 .

also reflect past oceanographic conditions, such as influences from polar, transitional, and subtropical waters.

During the last about $500,000 \mathrm{yr}$ (oxygen isotope stages 1-13), the abundance of Calcidiscus leptoporus suggests that sea-surface temperatures at Site 704 were warmer than at present only during oxygen isotope substage $5 \mathrm{e}$. The environment was similar to that of today during isotope stages 7 and 13. Site 704 experienced glacial conditions and was either south of the ACZ or located close to its northern edge during isotope stages $2,4,6,8,10$, and 12 . During stage 3 , conditions were intermediate glacial.

Below the oxygen isotope stage 13 interval, the sediments contain only low abundances of nannofossils, which may be due to glacial regimes of about 500,000 to $645,000 \mathrm{yr}$ ago. Nannofossils return in high abundance in the lower part of the analyzed sequence. This indicates that periods with comparatively warm (interglacial) conditions occurred between about 645,000 to about 680,000 yr ago. These warm periods were interrupted by periods with influx of polar waters.

During the last $500,000 \mathrm{yr}$, abundance fluctuations of nannofossils in subantarctic Hole 704A are similar to those in the subarctic Norwegian Sea. This indicates that climatic variations were in phase between the Northern and Southern hemispheres during this time period. Nannofossils are, however, rare in the Norwegian Sea in the interval from 620,000 to $650,000 \mathrm{yr}$, while they are abundant in the southern South Atlantic.

\section{TAXONOMIC LIST OF CALCAREOUS NANNOFOSSIL SPECIES}

Gephyrocapsa aperta Kamptner, 1963

Gephyrocapsa caribbeanica Boudreaux and Hay, 1969

Emiliania huxleyi (Lohmann, 1902) Hay and Mohler in Hay et al., 1967

Pseudoemiliania lacunosa (Kamptner, 1963) Gartner, 1969

Calcidiscus leptoporus (Murray and Blackman, 1898) Loeblich and Tappan, 1978
Gephyrocapsa muellerae Bréhérét, 1978

Coccolithus pelagicus (Wallich, 1877) Schiller, 1930

\section{ACKNOWLEDGMENTS}

We thank U. Bleil, P. F. Ciesielski, J. D. Hays, E. Hailwood, and D. Hodell for providing us with unpublished data and for scientific discussions. J. A. Crux thanks the British Petroleum Co. for financial support during ODP Leg 114.

\section{REFERENCES}

Backman, J., and Shackleton, N. J., 1983. Quantitative biochronology of Pliocene and early Pleistocene calcareous nannofossils from the Atlantic, Indian and Pacific oceans. Mar. Micropaleontol., 8:141-170.

Belanger, P. E., 1982. Paleo-oceanography of the Norwegian Sea during the past 130,000 years: coccolithophorid and foraminiferal data. Boreas, 11:29-36.

Berggren, W. A., Kent, D. V., and Van Couvering, J. A., 1985. The Neogene: part 2. Neogene geochronology and chronostratigraphy. In Snelling, N. J. (Ed.), The Chronology of the Geological Record. Geol. Soc. London Mem., 10:211-260.

Boudreaux, J. E., and Hay, W. W., 1969. Calcareous nannoplankton and biostratigraphy of the late Pliocene-Pleistocene-Recent sediments in the Submarex cores. Rev. Esp. Micropaleontol., 1:249292.

Bréhérét, J. G., 1978. Formes nouvélles quaternaires et actuélles de la famille des Gephyrocapsaceae (Coccolithophorides). C. R. Seances Acad. Sci. Ser. 3, 287D:447-449.

Eldholm, O., Thiede, J., et al., 1987. Proc. ODP, Init. Repts., 104: College Station, TX (Ocean Drilling Program).

Gard, G., 1988. Late Quaternary calcareous nannofossil biozonation, chronology and palaeo-oceanography in areas north of the FaeroeIceland Ridge. Quat. Sci. Rev., 7:65-78.

1989. Variations in coccolith assemblages during the last glacial cycle in the high and mid latitude Atlantic and Indian Oceans. In Crux, J. A., and Heck, S. E. van (Eds.), Nannofossils and Their Applications: Chichester (Ellis Horwood), 108-121.

Gard, G., and Backman, J., in press. Synthesis of Arctic and Subarctic coccolith biochronology and history of North Atlantic drift water influx during the last 500,000 years. In Bleil, U., et al. (Eds.), Geologic History of the Polar Oceans: Arctic versus Antarctic. NATO ASI Ser., Ser. C.

Gartner, S., Jr., 1969. Correlation of Neogene planktonic foraminifera and nannofossil zones. Trans. Gulf Coast Assoc. Geol. Soc., 19:585-599.

Hay, W. W., Mohler, H. P., Roth, P. H., Schmidt, R. R., and Boudreaux, J. E., 1967. Calcareous nannoplankton zonation of the Cenozoic of the Gulf Coast and. Caribbean-Antillean area and transoceanic correlation. Trans. Gulf Coast Assoc. Geol. Soc., 17:428-480.

Hays, J. D., Lozano, J. A., Shackleton, N. J., and Irving, G., 1972. Reconstruction of the Atlantic and western Indian Ocean sectors of the 18,000 B.P. Antarctic Ocean. In Cline, R. M., and Hays, J. D. (Eds.), Investigations of Late Quaternary Paleoceanography and Paleoclimatology. Mem. Geol. Soc. Am., 145:337-372.

Hays, J. D., and Shackleton, N. J., 1976. Globally synchronous extinction of the radiolarian Stylatractus universus. Geology, 4:649-652.

Imbrie, J. Hays, J. D., Martinson, D. G., McIntyre, A., Mix, A. C., Morley, J. J., Pisias, N. G., Prell, W. L., and Shackleton, N. J., 1984. The orbital theory of Pleistocene climate: support from a revised chronology of the marine $\delta^{18} \mathrm{O}$ record. In Berger, A., Imbrie, J., Hays, J., Kukla, G., and Saltzman, B. (Eds.), Milankovitch and Climate (pt. 1): Norwell, MA (Kluwer Acad.), 269-305.

Kamptner, E., 1963. Coccolithineen-Skelettreste aus Tiefseeablagerungen des Pazifischen Ozeans. Ann. Naturhist. Mus. Wien, 66:139-204.

Kellogg, T. B., Duplessy, J. C., and Shackleton, N. J., 1978. Planktonic foraminiferal and oxygen isotopic stratigraphy and paleoclimatology of Norwegian deep-sea cores. Boreas, 7:61-73.

Loeblich, A. R., and Tappan, H., 1978. The coccolithophorid genus Calcidiscus Kamptner and its synonyms. J. Paleontol., 52:13901392. 
Martini, E., 1971. Standard Tertiary and Quaternary calcareous nannoplankton zonation. In Farinacci, A. (Ed.), Proc. 2nd Planktonic Conf., Roma, 1971, 2:739-785.

Martinson, D. G., Pisias, N. G., Hays, J. D., Imbrie, I., Moore, T. C., Jr., and Shackleton, N. J., 1987. Age dating and the orbital theory of the ice-ages: development of a high-resolution 0 to 300,000 -year chronostratigraphy. Quat. Res. NY, 27:1-29.

McIntyre, A., Bé, A.W.H., and Roche, M. B., 1970. Modern Pacific coccolithophorida: a paleontological thermometer. Trans. N. Y. Acad. Sci., 32:720-731.

McIntyre, A., Ruddiman, W. F., and Jantzen, R., 1972. Southward penetrations of the North Atlantic Polar Front: faunal and floral evidence of large-scale surface water mass movements over the last 225,000 years. Deep-Sea Res., Part A, 19:61-77.

Ruddiman, W. F., and McIntyre, A., 1976. Northeast Atlantic paleoclimatic changes over the past 600,000 years. In Cline, R. M., and Hays, J. D. (Eds.), Investigation of Late Quaternary Paleoceanography and Paleoclimatology. Mem. Geol. Soc. Am., 145:11145.

Samtleben, C., 1980. Die evolution der Coccolithophoriden-Gattung Gephyrocapsa nach Befunden im Atlantik. Palaontol. Z., 54:91127.
Schiller, J., 1930. Coccolithineae. In Rabenhorst, L. (Ed.), Kryptogamen-Flora aus Deutschland, Osterreich und der Schweiz. Abt. Leipzig Akad. Verlagsgesellschaft, 10:89-267.

Shackleton, N. J., and Hall, M. A., 1984. Oxygen and carbon isotope stratigraphy of Deep Sea Drilling Project Hole 552A: Plio-Pleistocene glacial history. In Roberts, D. G., Schnitker, D., et al., Init. Repts. DSDP, 81: Washington (U.S. Govt. Printing Office), 599609.

Shipboard Scientific Party, 1988. Site 704. In Ciesielski, P. F., Kristoffersen, Y., et al., Proc. ODP, Init. Repts., 114: College Station, TX (Ocean Drilling Program), 621-796.

Thierstein, H. R., Geitzenauer, K. R., Molfino, B., and Shackleton, N. J., 1977. Global synchroneity of late Quaternary coccolith datum levels: validation by oxygen isotopes. Geology, 5:400-404.

Date of initial receipt: 16 May 1989

Date of acceptance: 19 December 1989

Ms 114B-134 